\title{
Adsorption of Copper by Two Different Size Gravels
}

\author{
A. Y. Abdulfatah, I. U. Salihi, and A. R. Anwar
}

\begin{abstract}
Laboratory experimental results are presented to determine the level of adsorption of copper by two different size gravels. A $6 \mathrm{~mm}$ pea-gravel and $30-60 \mathrm{~mm}$ gravels were used for the experiments in which the gravel samples were soaked and shaken in copper solutions prepared with varying concentrations of $10.0,20.0$ and $30.0 \mathrm{mg} / \mathrm{L}$. Effluents samples were collected and diluted to a ratio of 1 to $10 \mathrm{ml}$. These samples were monitored by an inductively couple plasma (ICP) and the detected concentrations were multiplied by 10 to balance the dilution effect. The Henry, Langmuir and Freundlich Isotherms were considered in each case for the determination of the adsorption level. The Freundlich model gave better results for the two gravel samples with a regression coefficient, $R^{2}$ of 0.999987 for the pea-gravel and 0.5717 for $30-60 \mathrm{~mm}$ gravels respectively. The straight line equation indicates good adsorption capacity of the Copper onto the pea-gravel more than the $30-60 \mathrm{~mm}$ gravels in accordance with the Freundlich isotherms.
\end{abstract}

Index Terms-Adsorption of species, copper, gravels, and isotherm models.

\section{INTRODUCTION}

Natural soils are known to have good affinity for heavy metals, e.g. [1], [2]. Copper in particular, has a strong soil affinity than do other metals like Zinc [2]. Copper is a natural element required by all plants and animals in their systems. It is both an essential nutrient and a drinking-water contaminant [3]. It is required at trace level by plants for their survival but its elevated level is undesirable [4]. The discharge of Copper and other metals from industrial and agricultural activities, and the operation of vehicles is a concern to the environment. The Copper released from the above sources dissolves in water, enters the ground and subsequently mixes with soils. Copper is known to have a very good solubility of 500g/l [5]. Dissolution of species occurs under a condition of under-saturation [6]. At a time when the soil solution is super-saturated with chemical species, solid crystals begin to form (precipitation). When a soil contains high concentration of heavy metals, the solubility of the metal is reduced and precipitation is favoured. The precipitation of heavy metals (e.g. $\mathrm{Pb}^{+2}$ ) is limited by $\mathrm{CO}_{3}$ or $\mathrm{SO}_{4}$ depending on the soil's redox potential. Complexation could be due to a biological process. It includes both inorganic and organic species [7],

Manuscript received April 16, 2013; revised July 11, 2013. This work was supported by the Petroleum Technology Development Fund (PTDF) Nigeria and Bayero University, Kano Nigeria. The presentation of this paper and the participation at the conference was solely sponsored by Bayero University, Kano Nigeria.

A. Y. Abdulfatah and I. U. Salihi are with the Department of Civil Engineering, Bayero University Kano, P.M.B. 3011 Kano Nigeria (e-mail: ayabdulfatah.civ@buk.edu.ng; iusalihi.civ@buk.edu.ng).

A. R. Anwar is with the Civil Engineering Department, University of Ilorin, P.M.B. 1515, Ilorin Nigeria (e-mail: saiyadianwar@yahoo.com).
[8].

It is known that heavy metals exist in soil in organically complexed forms or metal salts. Organic matter affects heavy metals retention and movement in soil/water [6]. This is because of the metals' high affinity for organic substances. Copper, Nickel and Lead are among the heavy metals with highest affinity for organic matter [7]. A metal bonding on organic matter occurs in the form of ionic exchange between $\mathrm{H}^{+}$and the metals in an acidic condition. Reference [9] reported good models that relate the sorption of heavy metals with clay minerals, organic matter and metal oxides. The reaction of heavy metals with organic matter occurs in different ways [6]. These include reaction with dissolved organic carbon (DOC), reaction with suspended organic matter (SOM) and reaction with bottom sediments.

Adsorption which is the accumulation of chemical species occurs at the interface between the surfaces of soil-solid and soil-solution phases [6]. This process involves the attachment of dissolved species from the soil solution onto the solid surfaces. The reversed process of releasing these species from the solid surfaces back to the soil-solution is referred to as desorption [8]. In other words, adsorption can be defined as a transfer of ions from the soil solution to the solid surfaces [7].

Some factors affect the sorption process. These are (1) the characteristics of the contaminants e.g. solubility; (2) characteristics of the soil, e.g. mineralogy, permeability, porosity and surface properties; and (3) characteristics of the soil-solution, e.g. pH value, salt and organic contents. Soils possess good adsorbents (clays and organic substances) that effectively remove adsorptives (ions/molecules) from solution [7]. Accordingly, soil is regarded as a good final destiny for the adsorbates (i.e. heavy metals) [10]. The process of adsorption involves physical forces such as the Van-Der Waals forces, and chemical forces such as the inner sphere complexation forces [6]. The excess potential energy of the molecules can be reduced by the attraction of other substances at the interface [11]. Adsorption is divided into two main types; (1) Physical adsorption, involving intermolecular forces in which Van der Waals forces and hydrogen bonds bind the molecules of the adsorbent and adsorbate together, (2) Chemical adsorption (Chemisorption), which involves valence forces through sharing or exchange of electrons between the adsorbent and adsorbate as covalent forces. Solid materials provide sufficient surface areas for the activities of adsorbate and the rate of adsorption depends on this surface area, as well as temperature and $\mathrm{pH}$ [11]. Three main models; Henry (linear curve), Langmuir (hyperbolic curve), and Freundlich (parabolic curve) were considered here to study the adsorption of Copper by two different size gravels. 


\section{MATERIALS AND METHOD}

A $6 \mathrm{~mm}$ size pea-gravel and a second gravel sample of $30-60 \mathrm{~mm}$ size range were used in this study. Three different weights each of the two samples; $6 \mathrm{~mm}$ pea-gravel and 30-60 $\mathrm{mm}$ gravel were placed in 6 number $250 \mathrm{ml}$ plastic conical flasks. The samples were soaked in Copper solutions prepared with varying concentrations; 10.0, 20.0 and 30.0 part per million (ppm) equivalent to $\mathrm{mg} / \mathrm{L}$. The flasks were capped and shaken at 200 revolutions per minute (rpm) for 30 minutes at $25{ }^{0} \mathrm{C}$ temperature as shown in Fig. 1. Effluents samples were collected and diluted at a ratio of 1 to $10 \mathrm{ml}$. Effluents concentrations were monitored by an inductively couple plasma (ICP) Spectrophotometer and the detected concentrations were multiplied by 10 to balance the dilution effect.

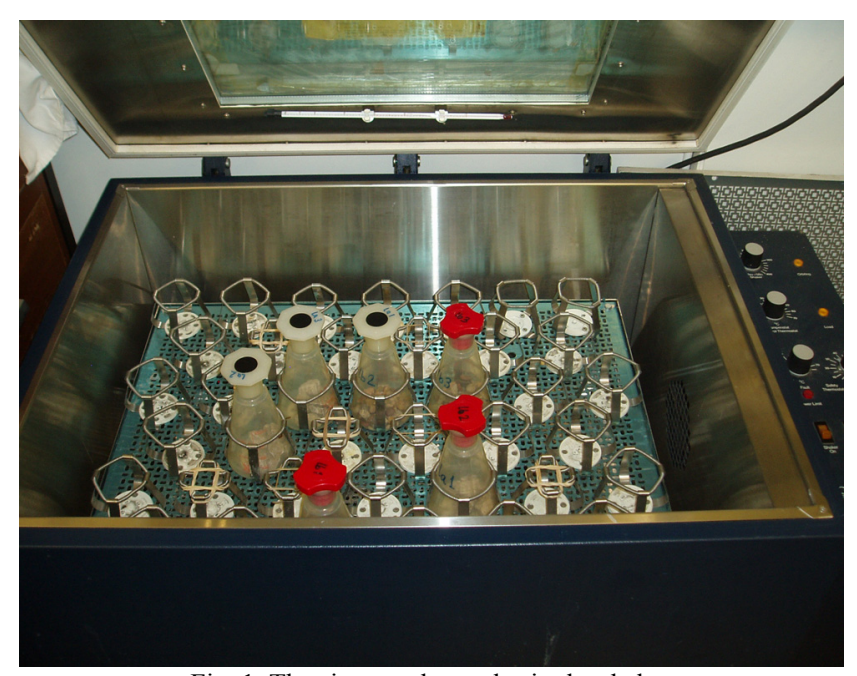

Fig. 1. The six gravel samples in the shaker

The Freundlich and Langmuir models were re-arranged to yield linear equations just like Henry's model [12], which is explained below.

1) The Henry's (linear) model is expressed as:

$$
Q_{e}=K_{d} C_{e}
$$

where $Q_{e}$ is adsorption density at equilibrium solute concentration ( $\mu \mathrm{g}$ of adsorbate per gram of adsorbent); $C_{e}$ is the equilibrium concentration in solution $(\mu \mathrm{g} / \mathrm{l})$, and $K_{d}$ is the partitioning (distribution) coefficient. This model is most suitable for low concentrations of contaminants but higher concentrations such as those used in this study require the use of the other two models [13].

2) The Langmuir model is expressed as:

$$
Q_{e}=\frac{X_{m} K C_{e}}{1+K C_{e}}
$$

where $X_{m}$ is the maximum adsorption capacity corresponding to complete monolayer coverage ( $\mu \mathrm{g}$ of solute adsorbed per gram of adsorbent); $K$ is the Langmuir constant related to energy of adsorption. $Q_{e}$ and $C_{e}$ are as described previously. Equation (2) is re-arranged to a form of linear equation:

$$
\frac{C_{e}}{Q_{e}}=\frac{1}{X_{m} K}+\frac{C_{e}}{X_{m}}
$$

where $\frac{1}{X_{m}}$ is the slope of the equation and $\frac{1}{X_{m} K}$ is the intercept.

3) The Freundlich model is expressed as:

$$
Q_{e}=K_{f} C_{e}^{1 / n},
$$

This could be rearranged to give the following:

$$
\ln Q_{\mathrm{e}}=\ln K_{f}+1 / n \ln C_{e}
$$

where $Q_{e}$ and $C_{e}$ remain the same as above and $K_{f}$ and $n$ are empirical constants. The slope of the equation equals $1 / n$ and the intercept is $\ln K_{f}$.

\section{REsults OF THE AdSORPTION TESTS}

The test results for the two gravel samples $(6.0 \mathrm{~mm}$ and 30 to $60 \mathrm{~mm}$ ) are presented below based on the Henry, Langmuir and Freundlich Isotherms in each case.

\section{A. First Sample ( $6.0 \mathrm{~mm}$ size pea-gravel)}

Tables I and II show Copper batch adsorption test results for the pea-gravel with sample calculations shown in the text.

Sample calculations for observation No. 1:

Hence $Q_{e}=0.4609 \mu \mathrm{g} / \mathrm{g}$ of gravel, $C_{e}=10000 \mu \mathrm{g} / \mathrm{l}, C_{e} / Q_{e}=$ $10000 / 0.4609=21$ 697. Similarly, all the required parameters for the three isotherms were calculated and tabulated in Tables III to V.

TABLE I: COPPER ADSORPTION RESULTS FOR PEA-GRAVEL

\begin{tabular}{|c|c|c|c|}
\hline $\begin{array}{l}\text { Observations } \\
\text { Number }\end{array}$ & Influent $(\mathrm{ppm})$ & $\begin{array}{l}\text { Effluent } \\
(\mathrm{ppm})\end{array}$ & $\begin{array}{l}\text { Mass of sample } \\
(\mathrm{g})\end{array}$ \\
\hline 1 & 10.000 & 9.8451 & 84.0734 \\
2 & 20.000 & 18.8700 & 79.8750 \\
3 & 30.000 & 25.7000 & 90.0658 \\
\hline
\end{tabular}

TABLE II: COPPER ADSORPTION RESULTS FOR PEA-GRAVEL

\begin{tabular}{|c|l|l|l|c|}
\hline $\begin{array}{l}\text { Observations } \\
\text { Number }\end{array}$ & $\begin{array}{l}\text { Influent } \\
(\mu \mathrm{g} / \mathrm{l})\end{array}$ & $\begin{array}{l}\text { Effluent } \\
(\mu \mathrm{g} / \mathrm{l})\end{array}$ & $\begin{array}{l}\text { Amount } \\
\text { absorbed } \\
(\mu \mathrm{g})\end{array}$ & \% Absorbed \\
\hline 1 & 10000 & 9845 & 155 & 1.5500 \\
2 & 20000 & 18870 & 1130 & 5.6500 \\
3 & 30000 & 25700 & 4300 & 14.3300 \\
\hline
\end{tabular}

1) Henry Isotherm:

TABLE III: QUILIBRIUM CONCENTRATIONS AND DENSITIES

\begin{tabular}{|c|c|c|}
\hline Observations No. & $C_{e}(\mu \mathrm{g} / \mathrm{l})$ & $Q e(\mu \mathrm{g} / \mathrm{g})$ \\
\hline 1 & 10000 & 0.4609 \\
2 & 20000 & 3.5368 \\
3 & 30000 & 11.9357 \\
\hline
\end{tabular}

2) Langmuir Isotherm:

TABLE IV: QUILIBRIUM CONCENTRATIONS AND DENSITY RATIOS

\begin{tabular}{|c|c|c|}
\hline Observations No. & $C_{e}(\mu \mathrm{g} / 1)$ & $C_{e} / \mathrm{Q}_{\mathrm{e}}$ \\
\hline 1 & 10000 & 21,697 \\
2 & 20000 & 5,655 \\
3 & 30000 & 2,513 \\
\hline
\end{tabular}


3) Freundlich Isotherm:

TABLE V: SUMMARY OF RESULTS

\begin{tabular}{|c|c|c|c|c|}
\hline $\begin{array}{c}\text { Observations } \\
\text { Number }\end{array}$ & $C_{e}(\mu \mathrm{g} / \mathrm{l})$ & $\begin{array}{c}Q_{e}(\mu \mathrm{g} / \mathrm{g} \text { of } \\
\text { gravel })\end{array}$ & $\ln C_{e}$ & $\ln Q_{e}$ \\
\hline 1 & 10000 & 0.4609 & 9.2103 & -0.7745 \\
2 & 20000 & 3.5368 & 9.9034 & 1.2632 \\
3 & 30000 & 11.9357 & 10.3090 & 2.4795 \\
\hline
\end{tabular}

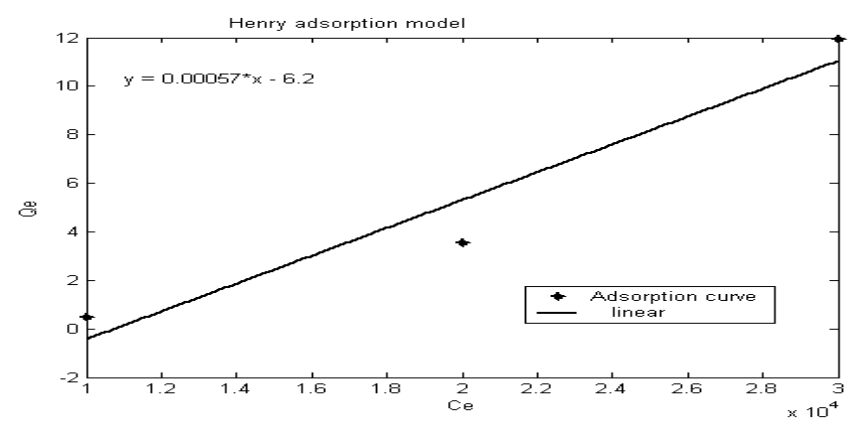

Fig. 2. Henry adsorption curve for pea-gravel

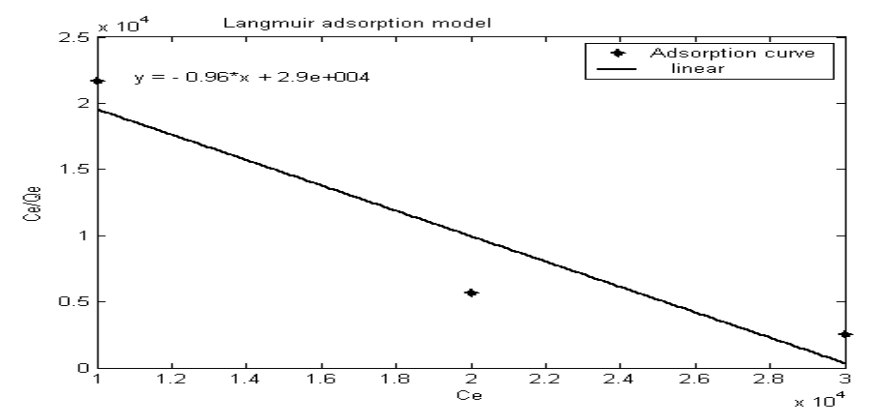

Fig. 3. Langmuir adsorption curve for pea-gravel

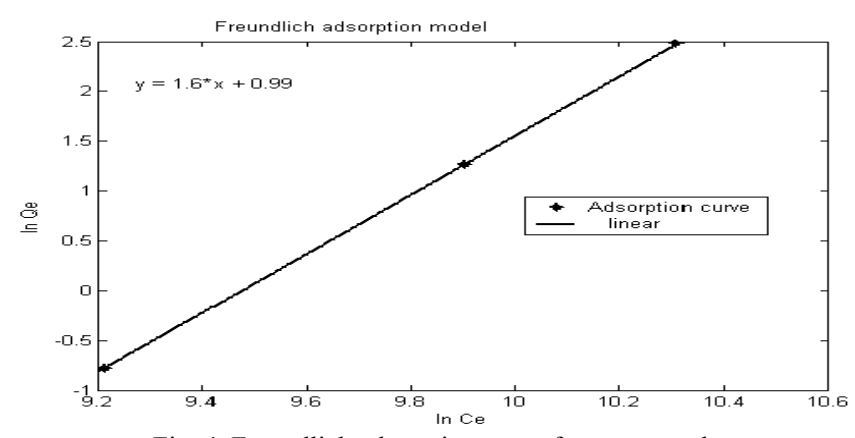

Fig. 4. Freundlich adsorption curve for pea-gravel

From the graphs in Fig. 2-4, the regression coefficients $\mathrm{R}^{2}$ are: from (Fig. 2) Henry model 0.933067, (Fig. 3) Langmuir model 0.869019, and (Fig. 4) Freundlich model 0.999987. Freundlich isotherm in (Fig. 4) gave a better result with $\mathrm{R}^{2}$ nearly unity and is a better representation than the Henry and Langmuir models in this case. The slope and intercept of Fig. 4 are 1.6 and 0.99 respectively. Therefore, the value of

$$
\mathrm{n}=\frac{1}{1.6}=0.625 \text {, and } \ln K_{f}=0.99, K_{f}=2.69 \text {. }
$$

The straight line equation indicates adsorption of $\mathrm{Cu}$ onto the pea-gravel according to the Freundlich isotherms. The regression coefficient of approximately unity is an indication of perfect linearity. A value of $n$ less than unity indicates a low adsorption intensity of Copper by the pea-gravel and the value of $K_{f}$ greater than 2 indicates a good adsorption capacity.

\section{B. Second Sample (30 to $60 \mathrm{~mm}$ gravel)}

Tables VI and VII show Copper batch adsorption test results on the bigger gravel samples with sample calculations shown in the text.

TABLE VI: COPPER ADSORPTION RESULTS FOR 30 TO 60 MM GRAVEL

\begin{tabular}{|c|c|c|c|}
\hline $\begin{array}{c}\text { Observation } \\
\text { Number }\end{array}$ & $\begin{array}{c}\text { Influent } \\
(\mathrm{ppm})\end{array}$ & $\begin{array}{c}\text { Effluent } \\
(\mathrm{ppm})\end{array}$ & $\begin{array}{c}\text { Mass of } \\
\text { sample }(\mathrm{g})\end{array}$ \\
\hline 1 & 10.000 & 9.8020 & 72.5709 \\
2 & 20.000 & 18.7100 & 79.5633 \\
3 & 30.000 & 29.3000 & 78.9727 \\
\hline
\end{tabular}

TABLE VII: COPPER ADSORPTION RESULTS FOR 30 TO 60 MM GRAVEL

\begin{tabular}{|c|c|c|c|c|}
\hline $\begin{array}{c}\text { Observation } \\
\text { Number }\end{array}$ & $\begin{array}{c}\text { Influent } \\
(\mu \mathrm{g} / \mathrm{l})\end{array}$ & $\begin{array}{c}\text { Effluent } \\
(\mu \mathrm{g} / \mathrm{l})\end{array}$ & $\begin{array}{c}\text { Amount } \\
\text { absorbed } \\
(\mu \mathrm{g})\end{array}$ & $\begin{array}{c}\% \\
\text { Absorbed }\end{array}$ \\
\hline 1 & 10000 & 9802 & 198 & 1.98 \\
2 & 20000 & 18710 & 1,290 & 6.45 \\
3 & 30000 & 29300 & 700 & 2.33 \\
\hline
\end{tabular}

Sample calculations for observation 1:

The amount of $\mathrm{Cu}$ absorbed $=10000-9802=198 \mu \mathrm{g} / 1$ which is equivalent to $49.5 \mu \mathrm{g}$ per $250 \mathrm{ml}$ of Copper solution. Mass of gravel in $250 \mathrm{ml}$ solution was $72.5709 \mathrm{~g}$, the amount of $\mathrm{Cu}$ absorbed per gram of gravel is $0.6821 \mu \mathrm{g}$. Hence $Q_{e}=$ $0.6821 \mu \mathrm{g} / \mathrm{g}$ of gravel, $C_{e}=10000 \mu \mathrm{g} / \mathrm{l}, C_{e} / Q_{e}=10$ $000 / 0.6821=14661$. Similarly, all the required parameters for the three isotherms were calculated and tabulated in Tables VIII to X.

1) Henry Isotherm:

TABLE VIII: EQUILIBRIUM CONCENTRATIONS AND DENSITIES

\begin{tabular}{|c|c|c|}
\hline Observation No. & $C_{e}(\mu \mathrm{g} / \mathrm{l})$ & $Q e(\mu \mathrm{g} / \mathrm{g})$ \\
\hline 1 & 10000 & 0.6821 \\
2 & 20000 & 4.0534 \\
3 & 30000 & 2.2160 \\
\hline
\end{tabular}

2) Langmuir Isotherm:

TABLE IX: EQUILIBRIUM CONCENTRATIONS AND DENSITY RATIOS

\begin{tabular}{|c|c|c|}
\hline Observation No. & $C_{e}(\mu \mathrm{g} / \mathrm{l})$ & $C_{e} / Q_{e}$ \\
\hline 1 & 10000 & 14661 \\
2 & 20000 & 4934 \\
3 & 30000 & 1338 \\
\hline
\end{tabular}

3) Freundlich Isotherm:

TABLE X: SUMMARY OF TEST RESUlTS

\begin{tabular}{|c|c|c|c|c|}
\hline $\begin{array}{c}\text { Observation } \\
\text { No. }\end{array}$ & $C_{e}(\mu \mathrm{g} / \mathrm{l})$ & $\begin{array}{c}Q_{e}(\mu \mathrm{g} / \mathrm{g} \text { of } \\
\text { gravel })\end{array}$ & $\ln C_{e}$ & $\ln Q_{e}$ \\
\hline 1 & 10000 & 0.6821 & 9.2103 & -0.3826 \\
2 & 20000 & 4.0534 & 9.9034 & 1.3996 \\
3 & 30000 & 2.2160 & 10.3090 & 0.7957 \\
\hline
\end{tabular}

From the graphs in Fig. 5-7 the regression coefficients, $\mathrm{R}^{2}$ are: from (Fig. 5) Henry model 0.2065, (Fig. 6) Langmuir model 0.0111, and (Fig. 7) Freundlich model 0.5717. In this case, the Freundlich isotherm in (Fig. 7) gave fairly better $\mathrm{R}^{2}$ value of 0.5717 , which is greater than the values from the other two models and is a better representation than the other two. The slope and intercept of Fig. 7 are 0.69 and 0.6 respectively. The value of $\mathrm{n}$ is therefore $\frac{1}{0.69}=1.449$ and $\ln$ $K_{f}=0.6$, which means that $K_{f}=1.822$. A value of $\mathrm{n}$ greater 
than 1 indicates a good adsorption intensity and $K_{f}$ less than 2 indicates a low adsorption capacity of Copper by the second gravel sample. The major difference in $\mathrm{R}^{2}$ values between the two gravel samples is related to the surface areas of the samples.

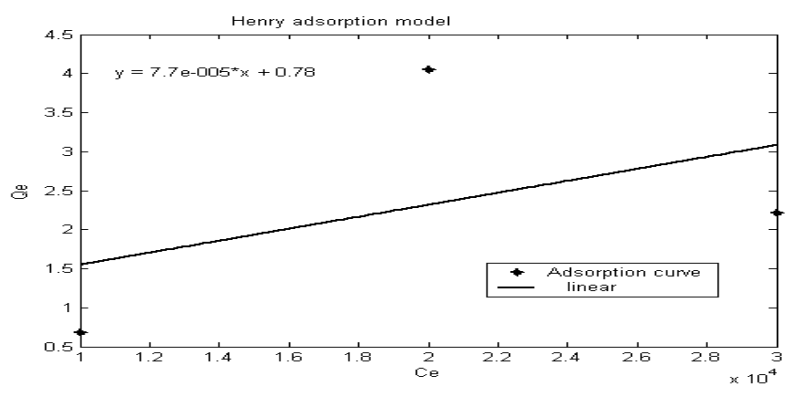

Fig. 5. Henry adsorption curve for 30-60 mm gravel

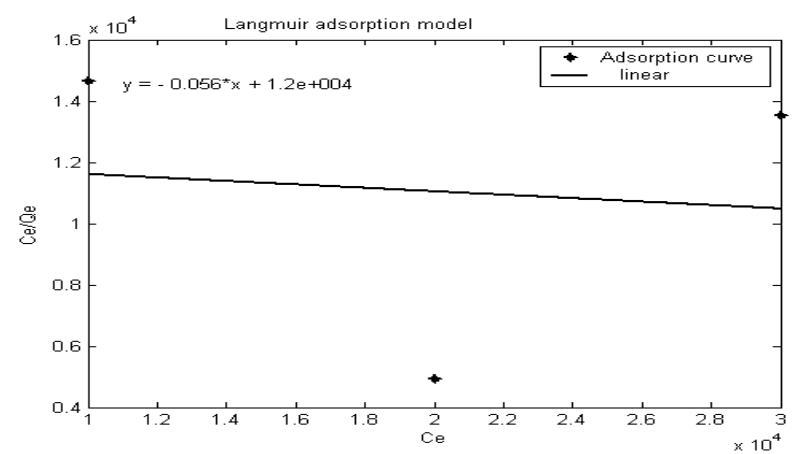

Fig. 6. Langmuir adsorption curve for 30-60 $\mathrm{mm}$ gravel

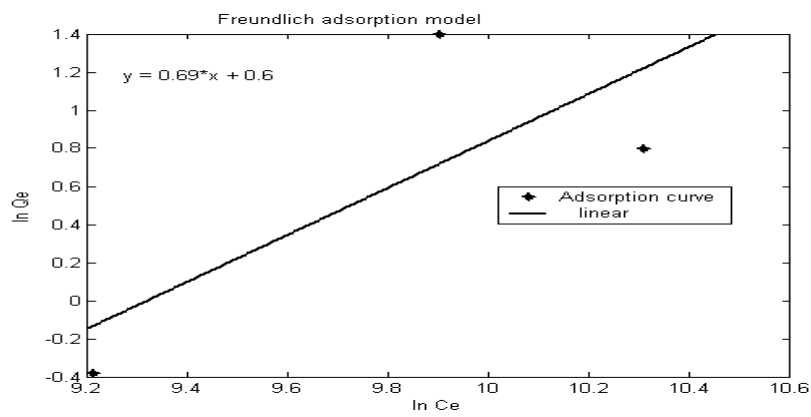

Fig. 7. Freundlich adsorption curve for 30-60 $\mathrm{mm}$ gravel

\section{REFERENCES}

[1] X. Cao, L. Q. Ma, D. R. Rhue, and C. S. Appel, "Mechanisms of lead, copper, and zinc retention by phosphate rock," Environmental Pollution, vol. 131, pp. 435-444, 2004.

[2] J. O. Agbenin and L. A. Olojo, "Competitive adsorption of copper and zinc by a Bt horizon of a savanna Alfisol as affected by $\mathrm{pH}$ and selective removal of hydrous oxides and organic matter," Geoderma, vol. 119, pp. 85-95, 2004.

[3] World Health Organisation (WHO) (2008). Guidelines for Drinking Water Quality, vol. $1,3^{\text {rd }}$ edi.

[4] A. J. Cardwell, D. W. Hawker, and M. Greenway, "Metal accumulation in aquatic macrophytes from southeast Queensland, Australia," Chemosphere, vol. 48, pp. 653-663, 2002.

[5] A. H. F. Mary, Standard Methods for the Examination of Water and Waste Water, $21^{\text {st }}$ Edition, APHA, Washington, 2005.

[6] D. L. Sparks, Environmental Soil Chemistry, $2^{\text {nd }}$ edition, Elsevier Science, California, 2003, pp. 115-185.

[7] J. B. Dominguez, (Editor). Soil Contamination Research Trends: Nova Science Publishers, New York, NY, U.S.A, 2008.

[8] H. D. Sharma and K. R. Reddy, Environmental Engineering, John Weily \& Sons Inc., New Jersey, 2004.

[9] H. M. Selim and W. L. Kingery, Geotechnical and Hydrological Reactivity of Heavy Metals in Soi, Lewis Publishers, Boca Raton, FL, U.S.A., 2003.

[10] M. J. Cal-Prieto, A. Carlosena, J. M. Andrade, M. L. Martinez, S. Muniategui, L. Mahia, and P. Prada, "Antimony as a tracer of the anthropogenic influence on soils and estukarine sediments," Water, Air, \& Soil Pollution, vol. 129, pp. 333-348, 2001.

[11] H. B. Bradl, Heavy Metals in the Environment: Origin, Interaction and Remediation, First edition, Elsevier Ltd. Netherlands, 2005.

[12] G. Sposito, The Surface Chemistry of Natural Particles, New York, U.S.A: Oxford University Press, 2004.

[13] R. Apak, E. Tutem, M. Hugal, and J. Hizal, "Heavy Metal Cation Retention by Unconventional Sorbents," Water Research, vol. 32, pp. 430-440, 1998.

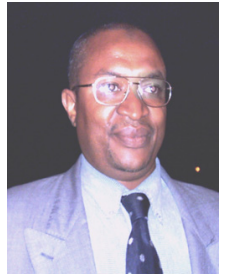

Kano Nigeria.

Dr. Abdulfatah is a member of the following: Nigerian Society of Engineers, British Geotechnical Association, Society for Underwater Technology and Offshore Engineering Society.

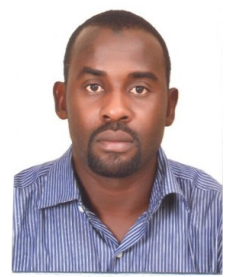

I. U. Salihi holds a Master Degree in Water Resources and Environmental Engineering (2012) and a Bachelor Degree in Civil Engineering (2006) both from Bayero University Kano Nigeria. He presently lectures in the Department of Civil Engineering, Bayero University, Kano-Nigeria.

Engr. Salihi is a Registered Engineer with the Council for the Regulation of Engineering in Nigeria (COREN) and also an Exco member of the Nigerian Society of Engineers (NSE)

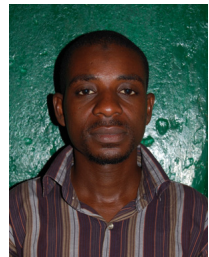

(NSE).
A. R. Anwar holds a Master Degree in Geotechnical Engineering (2012) and a Bachelor Degree in Civil Engineering (2006) both from Bayero University Kano Nigeria. He presently lectures in the Department of Civil Engineering, University of Ilorin Nigeria.Engr. Anwar is a Registered Engineer with the Council for the Regulation of Engineering in Nigeria (COREN) and also a member of the Nigerian Society of Engineers 